Journal of

Education and Practice (JEP)

UTILIZATION OF COMPUTER LITERACY SKILLS IN TEACHING AND RESEARCH BY LECTURERS IN COLLEGES OF EDUCATION IN SOUTH-EAST NIGERIA
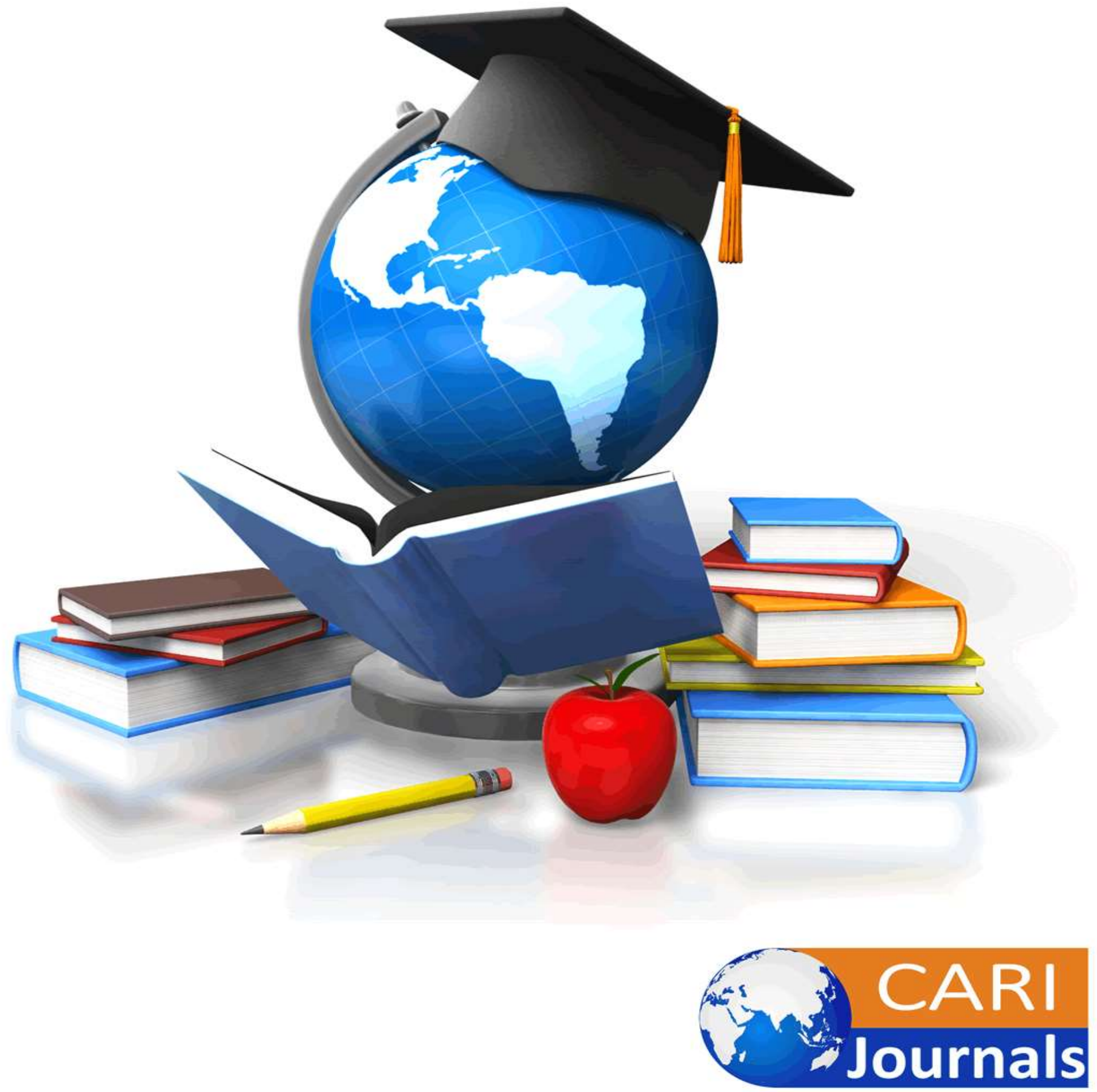


\title{
UTILIZATION OF COMPUTER LITERACY SKILLS IN TEACHING AND RESEARCH BY LECTURERS IN COLLEGES OF EDUCATION IN SOUTH-EAST NIGERIA.
}

\author{
Enemuo, Chinwe Juliana \\ Department of Science Education, Chukwuemeka, Odumegwu Ojukwu University, Igbariam. \\ Anambra State, Nigeria \\ Email: enemuojulian@gmail.com \\ Okigbo, Ebele Chinelo \\ Department of Science Education, Nnamdi Azikiwe University, Awka \\ Anambra State, Nigeria \\ Email: ec.okigbo@unizik.edu.ng
}

\begin{abstract}
Purpose: Every institution has its aims and objectives with activities to be carried out and resources to be utilize to achieved the expected goals. Utilization of computer skills requires adequate planning and regular practicing for effective performance. The purpose of the study was to examine the computer literacy skills utilized in teaching and research by Federal and State colleges of Education lecturers in South East Nigeria.

Methodology: Two research questions guided the study, while one null hypotheses was tested at 0.05 level of significance. Descriptive survey was adopted for the study, population of the study comprised of 2,102 lecturers in all the seven colleges of education in south east Nigeria. (Three federal and four state colleges of education) The sampling size was 630 using proportionate stratified sampling technique. The instrument for data collection was researcher -structured questionnaire titled Utilization of Computer Literacy skills Questionnaire (UCLSQ) which was validated by three experts. The reliability of the (UCLSQ) was established using Cronbach alpha formular to test for internal consistency of the items which yielded reliability indices of 0.82 . the questionnaire copies were administered to the lecturers with the help of three research assistants. Method of data collection, Data collected was analyzed using mean, standard deviation and independent t-test.
\end{abstract}

Results: The findings of the study further revealed among others that lecturers utilize only microsoft word skills and internet operation, but do not utilize microsoft power point, and microsoft excel, generally as shown in the study lecturers do no. Secondly, both Federal and state colleges of Education lecturers utilize microsoft word skills and internet operation skills but do not utilize microsoft powerpoint and microsoft excel skills. There is no significant difference between federal and state in utilizing microsoft word and internet operation skills, also there is a 
Journal of Education and Practice

ISSN 2520-467X (Online)

Vol.5, Issue No.3, pp $54-68,2021$

www.carijournals.org

significance difference between federal and state lecturers in utilization of microsoft power point and microsoft excel in teaching and research.

Policy recommendation: Based on the results of the study, it was recommended that the school management should on regular basis organize in house training programme for lecturers in the utilization of different computer skills for teaching and research and also provision of laboratory, personal laptops effective teaching and learning.

Keywords: Utilization, computer literacy skills, lecturers, Federal, State, colleges of Education

\section{INTRODUCTION}

The unique power of education acts as a catalyst for wider developmental goal of any nation. This developmental goal can only be fully realized, if education is equitable beyond mere enrolment or completion rates but meets the Sustainable Development Goals (SDGs). It is therefore vital that nations focus on the quality of teaching and learning in the classroom throughout the education lifecycle (Global Monitoring Report, World Bank, 2015). According to United Nations Educational, Scientific and Cultural Organization (UNESCO, 2014), the SDGs through the power of education is a serious financial investment which is currently beyond the reach of developing country like Nigeria, yet innovative solutions such as those offered by computer technology can go a long way in bridging the gap.

One of the most dramatic advances in communication potentials is found in the field of computer. Ani (2006) observed that computer presents materials and problem situations to students, guides their thinking, respond to their questions and manage their performance. Analysing, interpreting and presenting information in the education sector is an essential skill users of computer should possess if they will be relevant. Hence, being computer literate is fundamental to the acquisition of computer and usage.

Mbam (2012) defined computer as a tool for performing task fast, conveniently, effectively and more accurately. A sharp method adopted to help the common sense of man; a catalyst to development, effective and efficient management in all spheres of human endeavours are competently handled by computers. Computers are being used in wide range of operations like multi media for video and music, producing typed document, saving for future use, presentation of data, telephone lines, for communications and data analysis. Simonson, Maurer, Montag-Torardiand and Whitaker (2011) defined computer literacy skill as knowledge and ability to handle computer system, which includes being able to identify computer software and hardware, also being literate to handle softwares in computer system. Lecturers in Colleges of Education ought to be trained in order to know the computer literacy skills acquired and used by them in computer operation.

In Nigeria educational sector today, there is an urgent need for application of computer in teaching and learning. Hence, Amuche (2010) reported that teaching is becoming one of the most challenging professions because of rapidly expanding knowledge and advent of modern technologies. Invariably, it demands that lecturers adjust their pedagogical roles because they are 
Journal of Education and Practice

ISSN 2520-467X (Online)

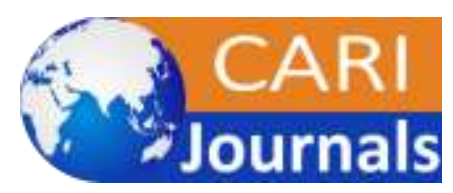

Vol.5, Issue No.3, pp $54-68,2021$

WwW.carijournals.org

the key to a successful learning and a good lecturer is expected to know what to teach and how to teach it convincingly. Aina and Alexander (2014), concluded that computer literacy skill could be measured in terms of ability to operate the computer system and use its application packages to accomplish a given task. According to Adeyinka and Mutala (2008), computer literacy skills is knowing some basics fundamental of computer, for example, use of Microsoft power point, internet operation, Microsoft word for preparation of lesson notes, typing of examination question papers, preparing students results, microsoft power point is used for projecting of lessons, internet is used for sending and receiving mails, uploading and downloading of document among others and excel is used in carrying out numerical operations. It also means having some level of comfort around computers rather than having some fear or a feeling of foreboding (New York Times, 2006). Adagunodo and Idowu ( 2013) defined computer literacy skills as the knowledge and ability to utilize computers and related technology efficiently, with a range of skills covering the levels of operation, from elementary use to computer programming and advanced problem solving. Utilization can be defined the act of employing, using, or putting into service, putting into practice . (https://www.dictionary.com/browse/use).

Colleges of Education aimed at producing teachers with highly computer literate and professionals, integrity, teachers who are dedicated, and with appropriate skills and intellectual depth that would facilitate easy achievement of the national goal. College of Education is the unit of tertiary education in Nigeria saddled with the responsibility of training teachers to obtain nondegree but qualitative professional certificate in education. However, it was observed that many teachers were not certificated and trained in utilizing computer skills. This observation was followed by a suggestion for greater expansion of intermediate education for intermediate teachers, which was targeted at upgrading the existing teaching force (Isiyaku, 2007). Lecturers can serve as training personnel to students and other lecturers in utilization of computer skills, it is this goal that motivates these questions: Are there lecturers who Utilize computer literacy skill? Do lecturers in federal and state Colleges of Education utilization of computer literacy skills in teaching and research depends on school ownership?

School ownership can be federal or state government, NGO or private sector based, should make lobbying for more investments in computers gadgets a priority. Most lecturers, instructors and students cited insufficient access to computers as the main obstacle in computer for education programmes, which most of the problem are generated by the ownership of the school, this is particularly relevant for educational institutions owned by State Government where the school or institution is often the only access point for computers and other computer facilities. Eresimadu in Amaizu (2013) observed that schools owned by State Government do not respond to teachers' problems appropriately. He found out that failure to address teachers' problems appropriately often resulted in crises. He therefore, advised administrators never to over-react during crisis situation in schools but rather that they should consider the relevance of teachers demands by negotiating directly with the teachers and keeping all channel of communication open at all times. Research by Fullan (2013) stated that most federal colleges of education are highly staffed and equipped with trending technologies like computer system and computer gadgets than that of state colleges of education.

Researchers have generally supported utilization of computer literacy skills in education which has many benefits for both lecturers and students (Ndawi, Thomas \& Nyaruwata, 2013). 
The benefits include; motivating students to learn, promoting independent work, and team work, course registration, teaching, setting of home work, preparing for examinations, typing of assignment, searching for information on the net, going for conferences and workshops, efficiency in lesson preparation and content delivery. These benefits motivated the present researchers.

\section{Statement of the problem}

Computer literacy skills is transforming education delivery across the world by enhancing the teaching and learning process. Its significant benefits have made its adoption in teaching and research in Colleges of Education essential. Based on this fact, federal and state Governments have made some efforts to re-orient lecturers towards utilization of computer literacy skills in colleges through its educational reforms, procurements and monitoring to improve the quality of instruction in schools. It is therefore expected that utilization of computer literacy skills for teaching and research by lecturers in colleges of education would tremendously improve the performance of students and on graduation in solving computer skills related problems in the society. These seemed not to be the trend in colleges of Education in the South-east, Nigeria.

\section{Purpose of the Study}

The purpose of the study was to investigate utilization of computer literacy skills in teaching and research by lecturers in Colleges of Education in south east Nigeria.

Specifically, the study sought to investigate;

1. Utilization of Computer literacy skills (Microsoft word, Internet operation, Power point and Microsoft Excel) by lecturers in Colleges of Education in South-east Nigeria in teaching and research

2. Utilization of Computer literacy skills (Microsoft word, Internet operation, Power point and Microsoft Excel) by male and female lecturers in colleges of Education in teaching and research

\section{Research Questions}

1. What are the mean score of computer literacy skills (Microsoft word, Internet operation, Power point and Excel) utilized lecturers in teaching and research in colleges of education in southeast Nigeria.

2. What are the mean score of computer literacy skills (Microsoft word, Internet operation, Power point and Excel) utilized by federal and state lecturers in teaching and research in colleges of education in southeast Nigeria.

\section{Hypotheses}


Journal of Education and Practice

ISSN 2520-467X (Online)

Vol.5, Issue No.3, pp $54-68,2021$

www.carijournals.org

1. The mean scores of Federal and State lecturers on their computer literacy skills (Microsoft word, Internet operation, Power point and Excel) utilization in teaching and research will not differ significantly.

\section{Methodology}

The descriptive survey research design was adopted for this study. According to Nworgu (2015) descriptive survey research are those studies which aim at collecting data and describing in a systematic manner the characteristics features or facts about a given population. Survey research design was used because it is determinant factor in the choice of the population and sample to be studied.

\section{Population and Sample}

The population of the study comprised 2102 lecturers in the seven Colleges of Education in South East Nigeria. The sample for the study consists of 630 (three federal and four state) colleges of education. Proportionate stratified sampling technique were used to drawn the lecturers in each of the faculties/schools from the seven colleges of education under study using $30 \%$ of the population from each college.

\section{Instrument for data collection}

Structured questionnaire was developed by the researcher based of the review of related literature and research questions guiding the study. The questionnaire was titled utilization of computer literacy skills questionnaire (UCLSQ) The questionnaire was two parts, I and II. Part 1 contains the background information of the respondents such as name of school, school type, and area of specialization. Part 11 of the questionnaire is in four sections A, B, C and D which contains 20 items on computer literacy skills utilized by lecturers and its response options were structured on five point rating scale of Always (A), Often (O), Occasionally (O), Rarely (R), and Never $(\mathrm{N})$.

\section{Method of Data Collection}

The researchers with the help of three research assistants distributed 671 copies of questionnaire out of which 630 copies were collected and completely filled given $94 \%$ return rate. The questionnaire has four response options, those whose responses are always were scored 5 points, often 4 points, occasionally 3 points, rarely 2 points and Never 1 points. True response has 2 points, while false response has 1 point. For positively worded items and vice for negatively worded or reversed items.

\section{Method of Data Analysis}

The data obtained was first collated and organized. Thereafter, the mean and standard deviation was used to answer the research questions. To test the Null hypotheses, t-test was used to in testing the hypothesis, Statistical Package for Social Sciences (SPSS) version 21 was used to analyze data.

In taking decision on computer literacy skills utilized, items with mean scores of 3.0 and above was regarded as utilized while below 3.0 regarded as not utilized 
Journal of Education and Practice

ISSN 2520-467X (Online)

Vol.5, Issue No.3, pp $54-68,2021$

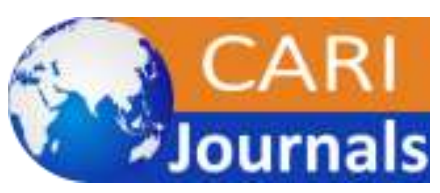

www.carijournals.org

\section{Results}

\section{Usage of computer literacy skills}

What are the mean scores of lecturers on the usage of computer literacy skills (Microsoft word, Internet operation, Power point and Excel) in teaching in colleges of education in south east Nigeria.

Table 1: Mean and standard deviation score in computer literacy skills used by colleges of education lecturers.

$\mathbf{N}=630$

\begin{tabular}{llllll}
\hline S/NO & ITEMS & MICROSOFT WORD & $\bar{X}$ & SD & REMARK
\end{tabular}

1 I use word processing to prepare

4.14

0.748

Often

students assessment record

2 I use Microsoft word to give students

Often assignment

3 I assess students document on CD or

0.78

Often

flash drive using word processing

$4 \quad$ I use word processing to type my

0.78

Often

5 I use word to prepare my note of lessons

4.11

0.75

Often

$=$

Sub total

4.04

0.77

Often

INTERNET OPERTAION

6 I use Internet to send information via e-

0.81

Often mails to the students

7 I give students assignment to search on

0.79

Often

8 I use Google class room with my students

4.13

0.80

Often 
Journal of Education and Practice

ISSN 2520-467X (Online)

Vol.5, Issue No.3, pp 54 - 68, 2021

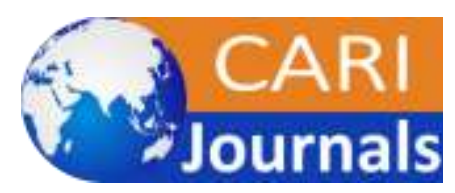

www.carijournals.org

9 I use zoom to interact with my students

2.98

1.24

Occasionally

10 I use internet to upload students results

2.15

1.10

Rarely

$$
\text { Subtotal }=
$$

2.74

0.95

\section{MICROSOFT POWER POINT}

11 I use power point to present Animation in

Rarely teaching

1.06

Rarely note of lessons

14 I use Microsoft power point to display a slide.

I use power point slide to present a note of lesson to the students

$1.08 \quad$ Rarely

15 I use more than two slides in teaching

Subtotal $=$

1.06

Rarely

\section{MICROSOFT EXCEL}

16 I use Excel in computing students grade

Rarely

17 I use excel to sort figures in ascending order

$1.06 \quad$ Rarely

18 I use excel to create graph

2.10

1.08

Rarely

19 I calculate numerical data using excel

2.09

20 I use excel to prepare lecture note

2.21

1.01

Rarely

$$
\text { Sub total }=
$$

2.16

1.11

Rarely

\subsection{7}


Journal of Education and Practice

ISSN 2520-467X (Online)

Vol.5, Issue No.3, pp $54-68,2021$

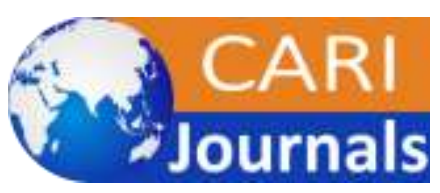

Www.carijournals.org

Table 2: Summary of Means and standard deviation scores of lecturers usage of computer literacy skills in teaching and research Colleges of Education in South-East Nigeria

\begin{tabular}{llccc}
\hline S/N & $\begin{array}{l}\text { COMPUTER } \\
\text { SKILLS }\end{array}$ & LITERACY & Lecturer & REMARK \\
\hline 1 & Microsoft word & $\mathbf{X}$ & SD & \\
2 & Internet operation & 4.04 & 0.77 & Often \\
3 & Microsoft power point & 2.74 & 0.95 & Rarely \\
4 & Microsoft excel & 2.22 & 1.08 & Rarely \\
& & 2.16 & 1.07 & Rarely \\
& & & & \\
& TOTAL & $\mathbf{2 . 7 9}$ & $\mathbf{0 . 9 7}$ & \\
\hline
\end{tabular}

The data contained in table 2 shows that lecturers in colleges of education often use microsoft word in teaching and research with mean score of 4.04. Furthermore, Internet operation, Microsoft power point and microsoft excel skills were rarely used by lecturers as contained in table 5 above.

Table 3: mean and standard deviation of federal and state lecturers on utilization of computer literacy skills in teaching and research.

$\mathbf{N}=$ Federal 434

State 196

\begin{tabular}{lllll}
\hline S/NO ITEM & $\begin{array}{l}\text { School } \\
\text { Type }\end{array}$ & $\bar{X}$ & SD & REMARK
\end{tabular}

\section{MICROSOFT WORD}

1

I use word processing to prepare students to prepare students assessment record

$\begin{array}{llll}\text { Federal } & 4.16 & 0.73 & \text { Often } \\ \text { State } & 4.10 & 0.77 & \text { Often }\end{array}$

2 I use Microsoft word to give students assignment

$\begin{array}{llll}\text { Federal } & 3.92 & 0.81 & \text { Often } \\ \text { State } & 3.80 & 0.83 & \text { Often }\end{array}$


Journal of Education and Practice

ISSN 2520-467X (Online)

Vol.5, Issue No.3, pp $54-68,2021$

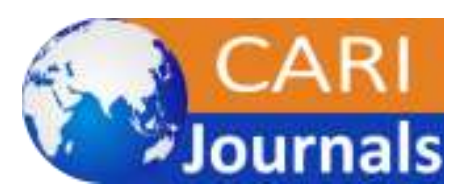

www.carijournals.org

3 I assess students document on CD or flash drive using word processing

Federal

4.09

0.75

Often

State

$3.97 \quad 0.82$

Often

4 I use word processing to type my students examination

Federal

4.04

0.77

Often question

State

3.93

0.79

Often

$5 \quad$ I use word to prepare my note of lessons

$\begin{array}{llll}\text { Federal } & 4.14 & 0.75 & \text { Often } \\ \text { State } & 3.98 & 0.78 & \text { Often }\end{array}$

Subtotal

Federal

4.07

0.76

Often

3.96

0.80

Often

\section{INTERNET OPERATION}

6 I use Internet to send information via e-mails to the students

$\begin{array}{llll}\text { Federal } & 3.99 & 0.81 & \text { Often } \\ \text { State } & 3.83 & 0.78 & \text { Often }\end{array}$

7 I give students assignment to search on internet.

Federal

4.13

0.77

Often

State

3.98

0.81

Often

$8 \quad$ I use Google class room with my students

$\begin{array}{llll}\text { Federal } & 4.13 & 0.79 & \text { Often } \\ \text { State } & 4.12 & 0.82 & \text { Often }\end{array}$

9 I use zoom to interact with my students

Federal

3.06

1.25

Often

State

2.80

1.20

Often

10 I use internet to upload students results

Federal

2.18

1.11

Often 
Journal of Education and Practice

ISSN 2520-467X (Online)

Vol.5, Issue No.3, pp 54 - 68, 2021

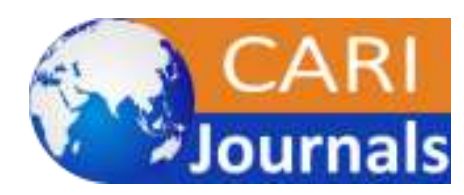

www.carijournals.org

$\begin{array}{llll}\text { State } & 2.09 & 1.07 & \text { Often }\end{array}$

Subtotal $=$

$\mathrm{N}=$ federal 434 State $=196$

ITEMS

SCHOOL TYPE $\bar{X} \quad$ SD REMARK

\section{MICROSOFT POWER POINT}

11 I use power point to present Animation in teaching

$\begin{array}{llll}\text { Federal } & 2.16 & 1.12 & \text { Rarely } \\ \text { State } & 2.11 & 1.09 & \text { Rarely }\end{array}$

12 I use power point to print out slides on note of lessons

$\begin{array}{llll}\text { Federal } & 2.30 & 1.08 & \text { Rarely } \\ \text { State } & 2.28 & 1.02 & \text { Rarely }\end{array}$

13 I use power point slide to present a note of lesson to the

Federal

2.19

1.11

Rarely students

State

2.17

1.02

Rarely

14 I use Microsoft word to display a slide.

$\begin{array}{llll}\text { Federal } & 2.25 & 1.06 & \text { Rarely } \\ \text { State } & 2.13 & 1.08 & \text { Rarely }\end{array}$

15 I use more than three slides in teaching

$\begin{array}{llll}\text { Federal } & 2.25 & 1.06 & \text { Rarely } \\ \text { State } & 2.13 & 1.08 & \text { Rarely }\end{array}$

Sub total

$\begin{array}{llll}\text { Federal } & 2.23 & 1.09 & \text { Rarely } \\ \text { State } & 2.16 & 1.06 & \text { Rarely }\end{array}$




\section{MICROSOFT EXCEL}

16 I use Excel in computing students grade

17 I use excel to sort figures in ascending order

$\begin{array}{llll}\text { Federal } & 2.23 & 1.11 & \text { Rarely } \\ \text { State } & 2.18 & 1.10 & \text { Rarely }\end{array}$

17. Iuse excel to sort figures in ascending order

$\begin{array}{llll}\text { Federal } & 2.18 & 1.06 & \text { Rarely } \\ \text { State } & 2.16 & 1.05 & \text { Rarely }\end{array}$

18 I use excel to create graph

$\begin{array}{llll}\text { Federal } & 2.15 & 1.11 & \text { Rarely } \\ \text { State } & 1.98 & 1.03 & \text { Rarely }\end{array}$

19 I calculate numerical data using excel

$\begin{array}{llll}\text { Federal } & 2.08 & 1.02 & \text { Rarely } \\ \text { State } & 2.12 & 0.98 & \text { Rarely }\end{array}$

20 I use excel to prepare lecture note

$\begin{array}{lllll} & \text { Federal } & 2.21 & 1.10 & \text { Rarely } \\ & \text { State } & 2.19 & 1.13 & \text { Rarely } \\ & & & & \\ \text { subtotal } & \text { Federal } & \mathbf{2 . 1 7} & \mathbf{1 . 0 8} & \text { Rarely } \\ & \text { State } & \mathbf{2 . 1 3} & \mathbf{1 . 0 6} & \text { Rarely } \\ & & & & \\ \text { Grand Total } & \text { Federal } & \mathbf{2 . 9 9} & \mathbf{0 . 9 7} & \\ & \text { State } & \mathbf{2 . 9 0} & \mathbf{0 . 9 6} & \end{array}$

Table 4: Summary of the Mean and Standard deviation scores of the computer literacy skills Utilize by lecturers in teaching and research in colleges of education in south east Nigeria. 
Journal of Education and Practice

ISSN 2520-467X (Online)

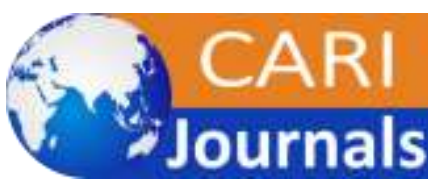

Vol.5, Issue No.3, pp $54-68,2021$

www.carijournals.org

\begin{tabular}{llcccccc}
\hline S/N & COMPUTER & $\bar{X}$ FEDERAL & REMARK & \multicolumn{2}{c}{$\overline{\text { STATE }}$} & \multicolumn{2}{c}{ REMARK } \\
& LITERACY SKILLS & X & SD & & \multicolumn{2}{c}{ SD } & \\
\hline 1 & Microsoft word & 4.07 & 0.76 & Often & 3.96 & 0.80 & Often \\
2 & Internet operation & 3.50 & 0.95 & Often & 3.36 & 0.94 & Occasionally \\
3 & Microsoft power point & 2.23 & 1.09 & Rarely & 2.16 & 1.06 & Rarely \\
4 & Microsoft excel & 2.17 & 1.08 & Rarely & 2.13 & 1.06 & Rarely \\
& TOTAL & $\mathbf{2 . 9 9}$ & $\mathbf{0 . 9 7}$ & & $\mathbf{2 . 9 0}$ & $\mathbf{0 . 9 6}$ & \\
\hline
\end{tabular}

Data contained in the table 4 shows that both federal and state lecturers often use Microsoft word skills with mean scores of 4.07 and 3.96. also federal lecturers often use internet operation with mean score of 3.50 while those in state occasionally use internet operation with mean score of 3.36. furthermore, both federal and state lecturers demonstrate low in Microsoft powerpoint and Microsoft excel with mean score of 2.23 and 2.17 for federal then 2.16 and 2.13 for state as shown in table 7 , therefore, lecturers in federal

\section{Hypothesis Testing}

The mean scores of federal and state college education lecturers on the computer literacy skills (Microsoft word, Internet operation, Power-point and Excel) usage in teaching and research will not differ significantly.

Table 5: t-test on the mean scores of federal and state lecturers on the computer literacy skills (Microsoft word, Internet operation, Power-point and Excel) usage in teaching and learning

\begin{tabular}{lllllllll}
\hline Computer literacy & Source of variation & $\mathbf{N}$ & $\mathbf{X}$ & $\mathbf{S D}$ & $\mathbf{d f}$ & Cal.t & $\mathbf{P . C a l}$ & $\mathbf{P} \geq \mathbf{0 . 0 5}$ \\
\hline MSword & Federal & 434 & 19.89 & 2.64 & & & & \\
& State & 196 & 20.35 & 2.52 & 628 & 2.103 & 0.036 & Sig \\
\multirow{2}{*}{ Internet Operation } & Federal & 434 & 16.85 & 2.52 & & & & \\
& State & 196 & 17.51 & 2.79 & 628 & 2.839 & 0.005 & Sig \\
Power Point & Federal & 434 & 11.03 & 4.11 & & & & \\
& State & 196 & 11.18 & 4.48 & 628 & 0.384 & 0.701 & Not Sig \\
Excel & Federal & 434 & 10.64 & 4.11 & & & & \\
& State & 196 & 10.86 & 4.35 & 628 & $0 . .603$ & 0.547 & Not Sig \\
\hline
\end{tabular}

Table 5 reveals that at 0.05 level of significance and 628 df the calculated $t$ is 2.103 on MS Word with the calculated p.value 0.036 and t 2.839 for internet with Pvalue 0.005 which are 
Journal of Education and Practice

ISSN 2520-467X (Online)

Vol.5, Issue No.3, pp $54-68,2021$

$\underline{\text { www.carijournals.org }}$

less than 0.05 , the mean scores of federal and state of college of education lecturers on the computer literacy skills (Microsoft word and Internet operation) usage in teaching and learning differ significantly.

In addition, table 5 shows that at 0.05 level of significance and $628 \mathrm{df}$ the calculated t0.384 for Power point with P.value 0.701 and t 0.603 for Microsoft Excel with P.vaue 0.547 which are greater than the critical P.value 0.05, there is no significant difference in the mean scores of federal and state college of education lecturers on the computer literacy skills (Power-point and Excel) usage in teaching and learning.

\section{Discussion of findings}

\section{Utilization of computer literacy skills by lecturers}

The finding of this study from table 1 shows that lecturers do not utilize the four skills as shown in table 4, they had a high mean score of 4.04 in Microsoft word, then in internet operation, Micorsoft power point and Microosft excel lecturers had a less mean score of 2.74, 2.22 and 2.16 with grand mean score of 2.79. This result is in agreement with Louis et al (2010). Who reported that most of African's are yet to embrace computer operation appropriately. Teachers in most of Asia, Europe, and Australia have adapted in the utilization of computer in the classroom. Similarly, (Lopez-Perez, Perez Lopez, Radriguez- Ariza \& Argente-Linares, 2013). Unfortunately, in Nigeria colleges of education and in most of the African countries, lecturers are still struggling with outdated gadgets in place of new technologies (Ansarki, Ayub \& Kadir, 2015). The findings of this present study shows that lecturers are not familiar and constantly utilizing internet operation, Microsoft powerpoint and Microsoft excel. They prefer using Microsoft word in teaching and research.

Table 3 shows that lecturers in federal and state utilize Microsoft word skills and internet operation skills but found to demonstrate low in Microsoft powerpoint and Microosft excel. There is no significance difference in federal and state utilization of computer literacy of lecturers in colleges of education in south east, Nigeria. One may not wonder about the revelation of this study due to the expensiveness of conducting a constant workshops and computer system connectivity in the schools. Therefore the null hypothesis of no significance difference was not rejected because the probability value of $(0.54)$ is greater than $(0.05)$. The mean ratings of lecturers in federal and state colleges of education indicates that the ratings of federal and state colleges of education lecturers in computer literacy skills do not differ significantly on the usage of Microsoft word, internet operation, Microsoft power point and excel in teaching and research in colleges of education in south-east Nigeria. Also, this findings is not in agreement with Fullan (1991) He also noted that most federal colleges of education demonstrate high in computer skills, highly staffed and equipped with trending technologies like computer system and computer gadgets than that of state colleges of education. If the school management is not committed to adopting change and particularly computer operation, then if one teacher goes on a course, the rest of the school sets up antibodies to any new ideas which the unfortunate teacher brings back into the school. Access to adequate technology is clearly a prerequisite for successful adoption of computer literacy skills among lecturers in federal and state colleges of education. 
Journal of Education and Practice

ISSN 2520-467X (Online)

Vol.5, Issue No.3, pp $54-68,2021$

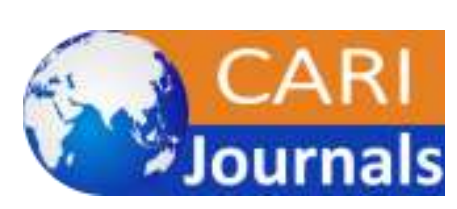

www.carijournals.org

Furthermore, findings of the study imply a need for lecturers in colleges of educations to constantly engage in intensive training on the use of computer skills and different computer applications such as Microsoft power point and excel, to maintain its application more for learning as with other facilities that are most often used than for social interactions. This will facilitate and encourage students to take charge of their own learning comfortably with ease as in the developed countries. This also implies government and stakeholders in tertiary institutions, making computer facilities adequately available for usage level of some literacy skills that is applied at synchronous mode.

\section{Conclusion}

The findings of the study reveals that Lecturers in federal and state colleges of education in south east, Nigeria were highly utilized Microsoft word and internet operation skills, while in they demonstrated low in the acquisition of Microsoft power point and excel. Based on the findings in research question 2, there is need for lecturers involvement for extensive practical work in the use of Microsoft powerpoint and Microsoft excel for the benefit of the students and the society

\section{Recommendation}

1. Colleges of education lecturers should enhance their skills regularly and stay up to date in their knowledge of technology such as computing skills through continual professional development trainings and workshops.

2. Government should provide internet facilities and adequate computer facilities in the colleges of education for constant usage among lecturers, especially lecturers in south east, Nigeria in order to facilitate their lecturing activities.

\section{References}

Adagunodo, R., \& Idowu, B. (2013). Gender difference in computer literacy among Nigeria undergraduates' students. A case study of Obafemi Awolowo University student, Nigeria. The African Symposium. An On -line Educational Research Journal, . 4. (3) ,59 -64.

Adeyinka, T. \& Mutula, S.M (2008). Gender differences in computer literacy among undergraduate students at the University of Bostwana: Implication for Library use. Malaysian Journal of Library and Information Sciences, 18, 59 -76.

Aina, J. \& Ogundele, A. (2014). Use of computers in schools. Ilorin: FHJK Publications.

Amaizu, V.N (2013). Strategies for Improving students personnel services in secondary schools in onitsha Education zone. Unpublished M.ED project, Department of Education, University of Nigeria, Nsukka.

Amuche, C.I (2010). "Entrepreneurial and ICT education as a means of achieving the objectives of vision 20:2020." A paper presented at the $9^{\text {th }}$ conference of the National Association of Research Development held at Nasarawa State University Keffi, September, 2010.

Ani, S. (2006). The age of Information and communication Technology, A three day workshop organized by UNESCO Nigeria at Enugu; $7^{\text {th }}$ January 2006. 
Journal of Education and Practice

ISSN 2520-467X (Online)

Vol.5, Issue No.3, pp $54-68,2021$

www.carijournals.org

Fullan,.(2013). Stratosphere: Integrating Technology, Pedagogy and change knowledge. Alberta Journal of Educational Research, Reviewed by Libbi, R. Miller; 2013. Vol.62, 4 Winter 2016, 429-432.

(https://www.dictionary.com/browse/use).

(https://www.dictionary.com/browse/use).

(https://www.naeyc.org/resources/pubs/vop/about-teacher-research

Isiyaku, K. (2007). The Training of NCE teachers in Nigeria, how far, how well. Nigerian Journal of Professional Teachers 2(7). Teacher Registration Council of Nigeria.

Mbam, B.C (2012). Computer literacy and operation. Green Light Computers. N0 28 New Market Road Abakaliki, Ebonyi State Pages 2-3.

Ndawi,V.E., Thomas, K.A.,\& Nyanwata, T.L. (2013). Barriers to effective integrations of Information and communication technology in Harere secondary school, International Journal of Science and Research. (IJSR), 2(9), 211-216.

Nwafor. C. (2015). The Impact assessment of information, technology and accounting practices in contemporary organizations "A paper presented at the national conference on e-learning \& cross Discipline at Shangri-la Hotel, Accra Ghana on $4^{\text {th }}$ May, 2011 retrieved Feb. 18, 2008 from http://InformationR.net/ir/103/paper229.html

Organization for Economic Cooperative and Development,(OECD) (2009). Glossary for statistical terms: Education and training statistics created on Tuesday, September 25, 2009. Last updated on Monday, April 28, 2003.

Segundo, E. \& Salazar, D. (2011). The efficacy of using power point presentations to improve grammar and vocabulary learning among students of the intermediate II level. Americano in Truyillo, peru repositorio instructional PIRHUA- Universided de piura.

Simonson, M. R, Maurer, M., Montag-Torardi, M. \&Whitaker, M. (2011). Development of standardized test of computer literacy a computer anxiety index. Journal Of Educational Computing Research, 3,231-247.

UNESCO, (2014). ICT competency standard for teachers: policy framework. UNESCO: Paris.

United Nations Development Program (2001).http://www.hrd.undp.org/en/cotent/humandevelopment report-2001.

Wikipedia, (2014). Definition of microSoft word processing. Retrieved on $22^{\text {nd }}$ March, 2020. www.wikipedia.com/definition of microSoft word processing. 